\title{
Literary Creativity and Transgeniality ${ }^{1}$
}

\author{
JÜRI TALVET
}

\begin{abstract}
There is hardly any doubt that most turning points in the history of small and minor literatures have been provoked from the outside, in the first place under direct influence of some new current engendered and spread from "centers", traditionally identified with major nations and linguistic communities. As compared with small nations, creative cultures of "centers" have historically enjoyed much more freedom, because (more than often) under the coverage of political-economic and military might they have been able to develop without looming existential threats from the outside.

At the same time, no culture is inherently homogeneous. Especially since the Modern Age conformist and rebellious creativity have been in a constant state of confrontation as well as mutual interactivity. Therefore, the history of cultural creativity is full of paradoxes and surprises, both in "centers" and "peripheries". Creative culture has nearly always retained at least a relative independence, in regard to the official society with its material power and business structures.

I would like to show that beyond a huge number of intertextualities extending from "centers" to "peripheries" (the physical and mental locus of small and minor cultures), easily traceable in formal and external signs of literary works, there exists in parallel a phenomenon which could be tentatively defined as "transgeniality".

I will try to reveal some of such transgenialities comparing the poetics and philosophy of (mainly) three poets, the Spaniard Antonio Gamoneda (born in 1931), the Yi-Chinese poet Jidi Majia (born in 1961) and the Estonian poet Juhan Liiv (1864-1913).
\end{abstract}

Keywords: transgenialities; intertextualities; Francesco Petrarca; François Villon; Jorge Manrique; Antonio Gamoneda; Jidi Majia; Juhan Liiv

1 This work was supported by institutional research funding IUT (No 20-1; 2014-2019) of the Estonian Ministry of Education and Research.

DOI: https://doi.org/10.12697/IL.2018.23.2.2 


\section{A Paradigmatic Prelude from the Poetic Past of the "Centers"}

Numerous examples of the use of the motive "Ubi sunt?" (Where are they?) can probably be detected and described in the history of world literature as well as national literatures of most nations, in "centers" and "peripheries" likewise, in a great variety of native languages. As a motive, it is surely an intertextual phenomenon. In all likelihood a long and continuous chain of "Ubi sunt?", amply extending in time and space, could be reconstructed and established.

Yet the question becomes more complicated as soon as one attempts to establish relations between some of the most famous literary works in which the motive occurs. Despite its centric position, the motive is just one element among many others forming the total image in a literary work. It alone cannot explain why a few chosen works making use of it have been included in the canon of world literature, while so many others have not. Further coincidences of formal and external features would probably not provide an answer either. On the contrary, the more there are coincidences - perfectly embraceable in a framework or chain of intertextualities - the less is the chance that such works would be universally applauded as great samples of world literature.

It means that non-coincidence, divergence and the novelty of the image are by far more important in artistic creativity than traceable intertextuality. The difference and rarity are the surest guarantees of value, not similarity or faithful imitation. Even if in any concrete work the object matter substantially differs, the intentional or unconscious borrowing of some especially rare and original element of the image would clearly limit the value of a work that establishes such intertextuality. All seems to depend on the degree of novelty. Thus, for example the interior monologue of James Joyce's Ulysses, and above all its variety when the author chose to drop all punctuation marks (as in Marion Bloom's final monologue) signaled radical newness in the novel genre. However, subsequently interior monologues were successfully employed by many other writers who also have their "canonized" place in the western share of world literature, with Virginia Woolf and William Faulkner in the same vanguard of the early employers of such a new narrative technique.

Indeed, as the history of science eloquently proves, all invented new techniques, whatever their degree of sophistication, can rapidly be learned, imitated and successfully employed by many, while their initial creators tend to be forgotten, because in science the "new" nearly always tends to prevail over the "old".

In arts and literature, on the contrary, the genuine, deeper authenticity of an image can seldom be reduced in its essence to the notions of "technique", "text" or "intertextuality". A common ground does exist between many outstanding works, but in every concrete case of a chef-d'œuvre a radical new 
individuality can be noticed. That is why I find the term "transgeniality" more proper than intertextuality, as applied to these often "invisible" connections that exist between different creative minds of the past and the present. Naturally, there is hardly any need to introduce a strict breach between both. Intertextuality and transgeniality largely overlap, with the main difference being that the latter constitutes a broader philosophical ground of affinities between creative minds, transcending formal and external common features of (inter)textualities. From that ground, new and greatly different artistic images may appear without losing anything of their authenticity and originality. Quite surely, such a transgeniality unites James Joyce (above all, in his Ulysses) with both François Rabelais (from whom, be the way, he might have borrowed the idea of suppressing punctuation marks between indirect and direct speech) and Miguel de Cervantes (as Joyce affirmed life's totality in a symbiosis, something intuitively graspable in Don Quixote's philosophy). Any writer following a straightforward intertextual line of the "dream logic" of the narrative image in Franz Kafka's works would probably be destined to fail to achieve the impact Kafka has had in world literature. However, from the common transgenial ground equally powerful individual images have later re-emerged in some of the work of the "magical-realistic" current of Latin American literature, as for instance in Juan Rulfo's Pedro Páramo and Gabriel García Márquez's Cien años de soledad. (On the other hand, they have been influenced by the older creative congeniality to be found in the magic of the chivalric prose fiction written in the epoch of the European Renaissance.)

To turn to poetry and the initially mentioned motif "Ubi sunt?", there is a fascinating intertextuality running from Francesco Petrarca's poem CCIXCIX (a sonnet, mid-14 $4^{\text {th }}$ century) to François Villon's Ballade des Dames du temps jadis (written roughly a century later) and one of the late medieval masterpieces of Spanish (Castilian) literature, Jorge Manrique's philosophic poem Coplas por la muerte de su padre, written between 1476 (the year of the death of Manrique's father) and 1479 (the year Manrique himself passed away).

As for the poetical form of these works, hardly any direct intertextuality could be traced. By Villon's lifetime the sonnet form had not yet been assimilated (from Italy) in France. Villon's poem is a ballad, in its late medieval French version. The sonnet had indeed reached Castile by the time Manrique wrote his famous chefd'œuvre Coplas por la muerte de su padre, but the form of the 40-stanza poem did not derive from the French ballad or Italian early Renaissance poetic patterns, but is one among many other original strophes in Spanish own poetic culture. Besides, Manrique invented his own version of copla - a strophe alternating twelve short (8-syllable) and even shorter (4-syllable) verse lines.

Theoretically there could have been a direct intertextual motif ("Ubi sunt?") deriving from Petrarca's sonnet in Manrique’s poem. Yet it is much more likely 
that the intertextual motif in Manrique is derived from Villon. Some passages of Manrique's Coplas are virtually identical with parts of images in Villon's stanzas in his Testament. Both works include a long series of rhetorical questions categorized under the "Ubi sunt?" and danse macabre motives, evoking episodes of the vanishing glory of former kings and governors, with death levelling in the final account all people, the rich and the famous, as well as the poor and the miserable.

Nonetheless, these motif parallels or intertextualities alone could hardly explain the eminence of the image in all three cases. Petrarca in his poem, as in the poetic cycle Canzoniere in general, imitates Dante Alighieri's Vita Nova, as the object of the poet's love is a young woman embodying human beauty and perfection. The image shift in Petrarca, in comparison with Dante, consists in its moving away from Vita Nova's abstract and allegorical character, in parallel with the image's absorption of intimate and confessional sensuousness. Ethical and aesthetic dimensions work together, but the latter, in the case of Petrarca, is moved to the forefront. In other words, the transgeniality departing from Petrarca is fundamentally lyrical. Given that the sonnet expresses the poet's sentiments over his beloved lady's death, the lyrical dimension merges with tragic existentiality.

\section{Poem 299 of Canzoniere}

Ov'è la fronte, che con picciol cenno

volgea il mio core in questa parte e 'n quella? Ov'è 'l bel ciglio, et l'una et l'altra stella ch'al corso del mio viver lume denno?

Ov'è 'l valor, la conoscenza e '1 senno? L'accorta, honesta, humil, dolce favella? Ove son le bellezze accolte in ella, che gran tempo di me lor voglia fenno?

Ov'è l'ombra gentil del viso humano ch'òra et riposo dava a l'alma stanca, et là 've i miei pensier' scritti eran tutti?

Ov'è colei che mia vita ebbe in mano? Quanto al misero mondo, et quanto manca agli occhi miei che mai non fien asciutti!
Where is the forehead, that could make my heart turn this way and that, with the slightest gesture? Where are the beautiful lashes and the two stars that gave their light to my life's path?

Where is the worth, the knowledge and the wit, the modest, honest, humble, sweet speech? Where are the beauties focused in her, that had their way with me so long?

Where is the gentle shadow of a human face that gave its hour of rest for my weary soul, and where my every thought was written?

Where is she who held my life in her hand? How this wretched world and how my eyes miss her, that have no hope of ever being dry!

(English translation by A. S. Kline, http://petrarch.petersadlon.com/canzoniere.html?poem=299) 
Both in Villon and Manrique the "Ubi sunt?" motif becomes involved in the broader danse macabre theme which began to spread in different culturalcreative manifestations through $15^{\text {th }}$-century western Europe. The greater part of Villon's Testament poems fit well into the general pattern of widely practiced popular satiric-didactic poetry of western Europe from the thirteenth century onwards. Villon stood out in this genre by his witty and eloquent images often boldly involving coarse naturalistic and sexual "low-life" details. However, Villon's rare and unrepeated individuality, in my opinion, is not so much revealed in the pattern of the "low" intertextuality, but just in its occasional and sudden interruption by lyrical-tragic transgeniality, as in the famous ballad known by the title "Ballade des dames du temps jadis".

Ballade des dames du temps jadis

Dictes-moy où, n'en quel pays, Est Flora, la belle Romaine ;

Archipiada, ne Thais, Qui fut sa cousine germaine ; Echo, parlant quand bruyt on maine Dessus riviere ou sus estan, Qui beauté eut trop plus qu'humaine? Mais où sont les neiges d'antan!

Où est la très sage Héloise, Pour qui chastré fut et puis moyne Pierre Esbaillant à Sainct-Denis ? Pour son amour eut cest essoyne. Semblablement, où est la royne Qui commanda que Buridan Fust gecté en ung sac en Seine ? Mais où sont les neiges d'antan!

La royne Blanche comme ung lys, Qui chantoit à voix de sereine, Berthe au grand pied, Bietris, Allys ; Harembourgis, qui tint le Mayne, Et Jehanne, la bonne Lorraine, Qu'Anglois bruslèrent à Rouen ; Ou sont-ils, Vierge souveraine ?... Mais où sont les neiges d'antan!

\section{Ballad of the ladies of old}

Tell me where, tell me in what land Is Flora, bonny Roman lady? Where Archippa, where Thais fair, Who was her cousin? O tell me! Now where will be Echo, who babbled Back at you o'er rivers and ponds, And whose beauty was more than human? $\mathrm{O}$ where are gone the snows of yore?

Where is Heloise chaste and wise, For whom unmanned and made a monk Was Abelard in Saint-Denis? For love of her he suffered so. In the same way where is the queen Who gave command that Buridan Be bagged and thrown into the Seine? $\mathrm{O}$ where are gone the snows of yore?

What befell the lily-white queen Who sang with her voice like a bird's; 'Big Feet' Bertha, Beatrix, Allys, Arembour, who ruled o'er Maine; And the sweet Joan from Lorraine, Whom the English burned at Rouen? Where are they all, Sovereign Lady? $\mathrm{O}$ where are gone the snows of yore? 
Prince, n'enquerez de sepmaine Ou elles ont, ne de cest an, Que ce refrain ne vous remaine : Mais où sont les neiges d'antan!
My Prince, seek not endlessly to know Where they are now, why time has passed; But only remember this chorus:

O where are gone the snows of yore?

(Translated by Florence Dujarric, 2005, http://www.projetbrassens.eclipse.co.uk/ pages/transballade.html)

The poet's own (imaginary or real) presence can be well observed throughout Villon's Testament. In the "low"-cue intertextuality, one of the outstanding European predecessors would be the Spaniard Juan Ruiz in his Libro de buen amor (first half of the $14^{\text {th }}$ century). On the other hand, in comparison with the "Ubi sunt?" lyrical-tragic transgeniality in Sonnet 299 of Petrarca, the difference is that the poet Villon "withdraws" his "self" from the image and while centering on motifs of exclusively intimate love, expands his observation to a variety of ladies, both mythical and historical, of the distant and recent past. Their short "life-stories", taken alone, would not grant the poem its tragiclyrical dimension. It is above all the famous refrain "Mais où sont les neiges d'antan!" that provides the image with its individual authenticity, by its sudden inclusion of "snow" - an element of nature (as well as of cosmic totality).

In this particular transgeniality, Jorge Manrique could be placed somewhere in between Petrarca and Villon. In his "Coplas por la muerte de su padre" the Castilian poet never reflects his own love or life. Yet neither is it a dance macabre "Ubi sunt?" exclusive description of the perishing glories of the past, alien to the poet himself. On the contrary, Manrique's main inspiration and pathos in the lines of tragic-lyric transgeniality is the death of his own father, an event that thoroughly shatters the son's interior life and makes him meditate profoundly on the limits of man's individual life and deeds. As Manrique's poem is much longer than Villon's ballad - and possibly also because of the new sensibility for nature, coming early to Spain from the incipient Italian Renaissance -, Manrique intertwines in his poetic image elements of nature outside man, as well as the danse macabre motif from the very beginning of his chef-d'œuvre.

\footnotetext{
Recuerde el alma dormida, avive el seso e despierte contemplando cómo se passa la vida, cómo se viene la muerte tan callando; cuán presto se va el plazer, cómo, después de acordado, da dolor;
} 
cómo, a nuestro parescer, cualquiere tiempo passado fue mejor.

Pues si vemos lo presente cómo en un punto s'es ido e acabado, si juzgamos sabiamente, daremos lo non venido por passado. Non se engañe nadi, no, pensando que ha de durar lo que espera más que duró lo que vio, pues que todo ha de passar por tal manera.

Nuestras vidas son los ríos que van a dar en la mar, qu'es el morir; allí van los señoríos derechos a se acabar e consumir;

allí los ríos caudales, allí los otros medianos e más chicos, allegados, son iguales los que viven por sus manos e los ricos.

English translation below is H. W. Longfellow's classical version:

$\mathrm{OH}$ let the soul her slumbers break, Let thought be quickened, and awake;

Awake to see

How soon this life is past and gone, And death comes softly stealing on, How silently!

Swiftly our pleasures glide away, Our hearts recall the distant day With many sighs;

The moments that are speeding fast We heed not, but the past, - the past, More highly prize. 
Onward its course the present keeps,

Onward the constant current sweeps, Till life is done;

And, did we judge of time aright, The past and future in their flight

Would be as one.

Let no one fondly dream again, That Hope and all her shadowy train Will not decay;

Fleeting as were the dreams of old, Remembered like a tale that's told, They pass away.

Our lives are rivers, gliding free

To that unfathomed, boundless sea, The silent grave!

Thither all earthly pomp and boast Roll, to be swallowed up and lost In one dark wave.

Thither the mighty torrents stray, Thither the brook pursues its way, And tinkling rill.

There all are equal; side by side The poor man and the son of pride Lie calm and still.

As an example of a lyrical infusion of the image, in parallel with the metaphor "neiges" ("snow") of Villon, Manrique "verduras de las eras" ("garlands, gay and green") and "rocíos de los prados" ("dewdrops of the grass") symbolize the ephemeral in nature and the ever-perishing world around man.

¿Qué se hizo el rey don Juan?

Los infantes de Aragón

¿qué se hicieron?

¿Qué fue de tanto galán, qué fue de tanta invención como trujeron?

Las justas y los torneos, paramentos, bordaduras, y cimeras, ¿fueron sino devaneos? 
¿Qué fueron sino verduras

de las eras?

$[\ldots]$

Las dádivas desmedidas, los edificios reales

llenos de oro,

las vajillas tan fabridas,

los enriques y reales

del tesoro,

los jaeces y caballos

de su gente, y atavíos

tan sobrados,

¿dónde iremos a buscallos?

¿qué fueron sino rocíos

de los prados?

Where is the King, Don Juan? Where

Each royal prince and noble heir

Of Aragon?

Where are the courtly gallantries?

The deeds of love and high emprise,

In battle done?

Tourney and joust, that charmed the eye,

And scarf, and gorgeous panoply,

And nodding plume,

What were they but a pageant scene?

What but the garlands, gay and green,

That deck the tomb?

The countless gifts, the stately walls, The royal palaces, and halls,

All filled with gold;

Plate with armorial bearings wrought, Chambers with ample treasures fraught Of wealth untold;

The noble steeds, and harness bright, And gallant lord, and stalwart knight, In rich array,

Where shall we seek them now? Alas!

Like the bright dewdrops on the grass,

They passed away. 
Yet, there is a substantial ideological modification in Manrique's philosophy, as compared with Villon. In the final part of his poem the Spanish poet, despite admitting the earthly life's radical misery, finds comfort in what he calls "vida tercera" ('third life') - a life dedicated to virtue and noble deeds, which, as the poet admits, would not be eternal either, but at least can confer to one's individual existence such dignity and value that it is remembered by the posterity.

\section{Antonio Gamoneda, Poet of Existential Cold and Burning Signs}

The poet Carlos Piera, as quoted on the cover text of Esta Luz (2004) says: "There is no other poetic work among us that would be so penetrated by cold and so conscious of fear."

"Among us" seems to refer to the Spanish poetical tradition in the first place, and its restriction to the post-Civil War period, i. e. the second half of the twentieth century.

If ever it is extended to the past glories of Spanish poetry, one could easily amend the statement in the line of Gamoneda's important parallels with Francisco de Quevedo and Calderón de la Barca, great baroque poets (the seventeenth century) in whose work existential meditation about death is a constant feature. Both have been in the focus of my own research, and I have also translated into Estonian some of their best-known works.

Before the Civil War (1936-1939), the poetic creativity of the famous 'Generación del ' 27 ' had its culmination in the existential tellurism of Federico García Lorca. It is not really far from Gamoneda's transgeniality, as in both poets the biological-sexual drive constitutes the hidden allusive depth of their poetic imagery. However, also important differences remain: in García Lorca the "burning image" includes utterly concrete and sensual metaphors, whereas in Gamoneda, by contrast, the words formed by abstract notions may be inflammatory.

Certain parallels with Gamoneda could be found, besides, in the poetic existentialism of the Catalan poet Salvador Espriu. ${ }^{2}$

The main Spanish researcher of Gamoneda's poetry, Miguel Casado, himself a poet, includes in his extensive and valuable introductory essay in Esta $l u z$ a series of references to foreign theorists, philosophers and critics (Ricoeur, Derrida, Heidegger, Blanchot, Barthes, Benjamin - all belonging to the vogue of postmodern key-thinkers). Even though Casado himself has translated into

2 In Estonian, a selection of Salvador Espriu's poetry, Labürindi lõpp, translated by Ain Kaalep and myself, appeared as early as 1977 (Tallinn: Perioodika, Loomingu Raamatukogu). 
Spanish several books by the well-known contemporary French poet Bernard Noël, he has not ventured to establish a tentative context including poets, their poetics and philosophy.

In my opinion, important parallels (such as radical pessimism, a meticulous and persistent observation and description of life's bodily decomposition in ourselves and around us), could indeed be observed between Gamoneda and Noël. More generally, in contemporary research of poetry there seems to be an urgent need to meditate on poetic phenomena in their wider comparative contexts, transcending national-linguistic traditions and entering the reign of the experience of world poetry. Each particular individuality is seldom reflected in merely formally describable features, or immediate intertextuality. To a much greater extent, the authenticity and originality of an image can be revealed in transgeniality - implicit philosophy, poetics and theory contained in poetic creativity itself, in the images of concrete poems as well as in the total image of a poet's work.

In the case of Gamoneda, his explicit poetics can hardly help a researcher. Gamoneda has indeed practiced a kind of a consciously free adaptation of some foreign poems, for instance, by the Turkish poet Nazim Hikmet (1961), and has rewritten Mallarmé's drama poem Hérodiade. Perhaps they reflect different stages of Gamoneda's search for his own poetic expression: from the initial idealism and a more or less open manner of expression to much more realistic and skeptical attitudes, to the scrutiny of life's decay, not relying so much on what is concrete and sensual but rather on the increased density of abstraction. For me, the tendency has analogies in the poetic work of the Estonian Ene Mihkelson (1944-2017). Hermeticism and introspection appear intensely combined with existentialism, as in her short poem published in Estonian in 1993 and in English translation in $2002^{3}$ :

\author{
THE SOUL SOMETIMES GASPS IN THE BREAST \\ It does not want to fly to the air in these \\ explosive times It grips the ribs like bars \\ But then it comes murmuring Houses tremble \\ in fear Because everything happens inside \\ not outside \\ (Trans. by J. Talvet and H. L. Hix)
}

3 Vello ceo nórdico. Poesía estonia contemporánea. Edición de Jüri Talvet y Arturo Casas. Boletín Galego de Literatura. Monografías. Universidade de Santiago de Compostela, 2002. 
In younger American poetry, I could find a similar transgeniality of existential hermeticism in the poetic work of H. L. Hix (born in 1960). Like Gamoneda, Hix creates long cycles of poems filled with abstract words and notions, close to prose, which however do not exclude occasional interruption by metaphors and symbols. Below is a sample from H. L. Hix's recent book (2017: 17). The abstract category of "vulnerability" is here, however - and not so typically of Hix -, carried through the poem by the application of occasional (end)rhymes and involving the presence of the poet's own "I". The symbolic story with birds, alluding to our loves as existential choices, comes thus provided with a concrete sensuous-intimate coloring:

Can one be vulnerable to oneself?

Their songs continued, regardless.

Not one tried to fly away.

I held each with equal tenderness.

The dream gave me reason why

I was tying with twine the wings

of each bird to its body.

Each with brightly-colored feathers,

each singing as if to me.

No reason why, from the windows

of a room god knows how high,

I dropped them. Or how, in each case

the vulnerability

was mine. They sang on, of my loss.

Not one needed to fly.

At a determined moment, any poet may reach his / her "own" individual language and image, without visible footprints of direct influences or intertextualities. It is possible that Gamoneda, totally unaware of his deed, has become a predecessor for a similar quest of expression of poetic philosophizing by somewhat younger poets who, for sure, have not at all been conscious of Gamoneda's work. 


\section{Existential-holistic Lyrical Transgeniality of Juhan Liiv and Jidi Majia}

Yet among my recent reading and translations of European and world poetry I would especially accentuate Gamoneda's parallels with two major world poets belonging to "peripheral" areas, at least in their relation with bigger Western "centers". One is my compatriot Juhan Liiv whose work I have researched in greater details (e. g. Talvet 2007; 2011). Liiv exemplifies a small "periphery”, strongly and inevitably restricted in its world resonance by the linguistic factor.

The other poet represents a smaller "periphery" within a much bigger one. Jidi Majia writes in Chinese, but the bulk of his poetic work has been dedicated to his native Yi nationality (between 2 and 6 million people who live dispersed in several Chinese historical regions, above all in the province of Sichuan).

These two poets, the Estonian Juhan Liiv and the Yi-Chinese Jidi Majia, though separated by an entire century, have a deep similarity of existentialist and holistic accents in their work. Both painfully look at the monstrous destruction of nature, pioneered and committed by the united forces of humankind's "progress" - industry, commerce, science and technology, ever incited by human greed and ambitions for power. Their poetry is a cry of anguish against man's alienation from nature and his crimes. Both defend passionately small nations in their almost hopeless struggle for the revindication of their culture, language and nation, ever menaced by leading big nations and their power rivalry.

Despite all differences, in regard to the work of Gamoneda, at least in some part of Liiv's and Jidi's poems a feature can be observed that is fundamental for the Spanish poet. It could be defined as "metaphorization of allegory", or "allegorization of metaphor". A kind of blending of both.

In the following poem by Jidi Majia, the ideological accent remains firmly on the anguish felt for his own minority nation's fate in the contemporary technological-commercial super-state China. It is the same feeling that can be observed running through Juhan Liiv's poetry. Similarly to Juhan Liiv's long series of well-known nation-centered poems, but especially to the poem “Ta lendab mesipuu poole” ('It Flies to the Hive', Liiv 2007: 93; 2013a: 45) Jidi's basic intimate-lyrical transgeniality reduces any schematization in the transmission of the allegorical idea. Nature's concrete presence in the image (represented by his native land's mountain range in Jidi and the honey-bee hurrying to their native hive) immerse both poems in sensuousness and senses, a human being's individual intimacy. 
Shade of Our Mountain Range

Following the Sun It Comes

Harbinger of Fate

It has no head or mouth

It makes no noise or fanfare

It trails a feathered cape of light

From a hidden place emerging

To comfort the weariness and longing of all being

And to the sheep's knuckles a diviner will throw

It imparts a nameless presentiment

This is the spirit of freedom

The talisman that guards the Nousu people

Those who lie in its quiet embrace

Will dream of stars coming out of dusk

Will find respite from screeching of steel

(Trans. by Denis Mair; in Jidi Majia 2014: 40)

In other words, what is the main feature in metaphor, senses and sensuousness - the very marrow of aesthetics - becomes blended by the miracle of individual creation with an allegoric-philosophical image.

A supreme paradigm of the afore said is offered in the glorious Spanish "Golden Age" literature, for example, by Pedro Calderón de la Barca's magnificent auto sacramental, El gran teatro del mundo (my Estonian translation, Suur maailmateater, 2007). The work of the Spanish genius of dramatic poetry is the quintessence of allegorical imagery. Yet in an extremely limited space, generally favoring schematic presentation in the arts, Calderón manages to produce long monologues of some of his drama characters, such as El Mundo (the World), thus thoroughly sensualizing and sensitizing the scheme. The abstraction catches fire, it becomes filled with life.

The English translation of the following untitled poem of Juhan Liiv appears here below for the first time ever in print. (The original Estonian poem appeared in print for the first time in 1953, that is, forty years after the poet's passing away.) It complements my discussion about creative parallels between Liiv and Jidi Majia in a recently published article, see Talvet 2018. In this powerful vision of Nature, which is itself subject to cosmic rhythms, the poetic image is transmitted in the traditional Finno-Ugric verse pattern (not really typical of Liiv). Even though the poem is allegorical in its origin, it becomes saturated with holistic sensitivity for the individual. Spring and the poet's "I" merge, human being's striving for independence from nature is declared useless. 
What surveys the village green, what squats there in the yard, what dangles from the woodpile, what squints through the clouds? Spring, that handsome gentleman it's him surveying the village green, peering through the gate, it's him squatting in the yard, dangling from the woodpile.

Where can I go to get away?

Where wander with my worries, where cavort with my cares?

Who should I flatter honey-tongued, who stroke with many fingers, ease in various ways?

But I am squatting in the yard, I'm dangling from the woodpile, wanting to play and sing, I don't see anyone moping, don't hear anyone complaining. What to do, how to behave:

mud bubbles in the yard, but spring peers through the gate.

Water flows, that gentleman, slush slows the brook, but the stern sun glares: water murmurs out loud.

Spring is squatting in the yard, dangling from the woodpile, spring peers through the gate, burdens the village green, barks in the front yard.

I don't see anyone moping, don't hear anyone mourning. 
What to do, how to behave?

Try to hide in the chimney, or under a bundle of brush: there he meets you, murmuring, there he bubbles through sod:

I don't see anyone moping!

But the heart harbors ills, winter worries wait, tender spots in brief life. -

But the spring carelessly barks.

Where, where escape myself?

Everywhere splitting and stretching. Independence lost -

the burden of spring!

The early bird hops there, the robin,

but it's not alone - a lark!

Wherever I seek shelter

I'm found out by spring.

(Written in 1908; first publication in Estonian in 1953; Liiv 2013b: 159-160; English translation by J. Talvet and H. L. Hix)

As an example of how such transgeniality is ever reborn, acquiring new individual aesthetic features, the cycle of poems "Incandescendencia y ruinas", initially written in Antonio Gamoneda's youth (the second half of the 1950s) could well serve.

Curiously enough, though I found the cycle in the Internet without difficulty, in the Gamoneda's fundamental anthology Esta luz it appears only in the Appendix (2004: 636-638). It called to my mind the publication history of a number of Juhan Liiv's poems. The poet's own preferences or the editor's "final" selection in a major anthology published years after the initial publication of a poem might not coincide with the taste of a reader who may have grounds for giving preference to the initially published version. In this concrete case I am indeed thankful to the Internet. For me, the mentioned cycle in its initial form is one of Gamoneda's most brilliant and radical poetic achievements in making abstract notions "burn" and in metaphorizing allegory. 
In this cycle, the poet "heart" becomes an allegoric character. The "I" of the poem initiates a dialogue with his heart which to all evidence distrusts "official" truths (both of the church and the state of another character, 'la cabeza sagrada debajo de la nieve' (the sacred head under snow). 'Heart' searches for its truths in life's totality, in 'agua salvaje' (savage water), in 'gruta donde abrasa la frescura' (the grotto where freshness scorches). 'Heart' is the 'habitante del fuego' (the inhabitant of fire) that allows 'perro milagroso' (the miraculous $\operatorname{dog}$ ) to eat in its interior; it is 'loco ruiseñor' (the mad nightingale), 'espuma prohibida' (the prohibited foam), 'anticanto de amor' (love's anti-canticle) that despite all its longing can hope for an absolution by 'un dios enloquecido' (the maddened god), or the human heart itself.

By the introduction of an invisible battle, antinomies (hidden or halfhidden oppositions in abstracts words and meanings) become deprived of their abstractness. Although the existential coldness prevails almost everywhere, such an interior battle is an inescapable proof of rebellion's significance. It also witness to important parallels with the work of other great creative spirits, such as Liiv or Jidi: signs burn in the poet's interior, opposing both the light of "official" sacredness and purity as well as of civilizing "progress", the false light of those 'que vienen con sus lámparas' (who come with their lamps) attempting to destroy and deafen nature in ourselves and around us, being the cause of 'que gima el acero en la ciudad rodeada de llanto' (steel's moaning in the city surrounded by weeping). (Gamoneda 2004: 438)

\section{Conclusion}

To a much greater extent than it is in the case of intertextualities, "invisible" transgenialities leave free space and freedom for an author's individual authenticity of the image. In particular, formal intertextualities tend to suppress and level it. By contrast, transgeniality is based on certain deeper parallelism or intimate closeness in the perceptual-philosophical understanding of the world. It can hardly be reconstructed or proved by a chain of intertextualities (visible and provable dependence) but by the almost inevitable overlapping of the search for truth in individual literary creativity.

In each concrete case the forms differ, while something of that difference is reflected also in the content. In any case, there is always room for surprises and originality, both on the micro-level of the image, as well as the image embracing the totality of an author's work. 


\section{Jüri Talvet}

talvet@ut.ee

Tartu Ülikool

Ülikooli 16-113

51014 Tartu

EESTI / ESTONIA

\section{References}

Gamoneda, A. 2004. Esta luz. Poesía reunida (1947-2004). Epílogo de Miguel Casado. Barcelona: Círculo de Lectores / Galaxia Gutenberg.

Hix, H. L. Rain Inscription. Wilkes University: Etruscan Press, 2017.

Jidi Majia. 2014. Shade of Our Mountain Range. Selected Poems. Ed. and trans by Denis Mair. Cape Town: Foreign Language Teaching and Research Publishing.

Liiv, J. 2007. Meel paremat ei kannata. The Mind Would Bear No Better. Ed. J. Talvet, trans. by J. Talvet and H. L. Hix. Tartu: Tartu Ülikooli Kirjastus, 2007.

Liiv, J. 2013a. Snow Drifts, I Sing. Selected Poems. Ed. J. Talvet, trans. by J. Talvet and H. L. Hix. Toronto: Guernica.

Liiv, J. 2013b. Lumi tuiskab, mina laulan. Valik luulet. Ed. J. Talvet. Tallinn: Tänapäev.

Talvet, J. 2007. Juhan Liiv ja tema olemasoluluule. Juhan Liiv and His Existential Poetry. - J. Liiv, Meel paremat ei kannata / The Mind Would Bear No Better. Tartu: Tartu Ülikooli Kirjastus, 2007, 7-28, 29-52.

Talvet, J. 2011. The Universe of the Mind of a Poet: Juhan Liiv's Philosophy and Poetics. - Interlitteraria, 16(1), 103-122.

Talvet, J. 2018. Comparative Literature, World Literature and Ethical Literary Criticism. Literature's "Infra-Other”. - Interlitteraria, 23/1, 6-18. 